\title{
Isolated delta-storage pool disease
}

INSERM

\section{Source}

INSERM. (1999). Orphanet: an online rare disease and orphan drug data base. Isolated delta-storage pool disease. ORPHA:248340

Isolated delta-storage pool disease is a rare, isolated, constitutional thrombocytopenia disorder characterized by defective formation and/or malfunction of platelet dense granules, as well as melanosomes in skin cells, resulting in variable manifestations ranging from mild bleeding and easy bruising to moderate mucous/cutaneous hemorrhagic diathesis and bleeding complications after surgery. 